\title{
PRELIMINARY STUDIES ON HEAVY METAL CONTENTS IN AQUATIC ORGANISMS FROM THE HORNSUND AREA, WITH A PARTICULAR REFERENCE TO THE ARCTIC CHARR [SALVELDVUS ALPINUS (L.)]
}

\author{
WSTEPNE BADANIA ZAWARTOŚCI METALI CIEŻKICH \\ W ORGANIZMACH WODNYCH Z REJONU HORNSUNDU ZE SZCZEGÓLNYM \\ UWZGLEDNIENIEM GOLCA (SALVELINUS ALPINUS (L.))
}

\author{
Faculty of Marine Fisheries and Food Technology, \\ Academy of Agriculture, \\ Srczecin
}

\begin{abstract}
Contents of $\mathrm{Hg}, \mathrm{Cd}, \mathrm{Pb}, \mathrm{Cu}$, and $\mathrm{Zn}$ were determined in the wreck bladder, barnacles, gammarids, euphausiids, and the Arctic charr collected in the Hornsund area in 1985-1986. Mercury was determined with CV AAS, while the remaining metals were studied with FAAS. Mercury levels were found to increase up the food chain; levels of $\mathrm{Cd}, \mathrm{Pb}$, and $\mathrm{Cu}$ were decreasing, while the $\mathrm{Zn}$ remained relatively stable. The authors are of the opinion that, when studying heavy metals along trophic chains, the entire food of animals instead of isolated food items should be analyzed. Moreover, the need to follow changes in contents of the metals studied during migrations of the fish from one habitat to another is emphasized. Sex-related effects were detected in heavy metal levels in certain organs. Mechanisms of defence against toxic metals were found to be better developed in females than in males. Differences in $\mathrm{Hg}, \mathrm{Cd}, \mathrm{Pb}, \mathrm{Cu}$, and $\mathrm{Zn}$ levels in various organs notwithstanding, the metal contents in fish muscles were in the lower part of the ranges found.
\end{abstract}

\section{INTRODUCTION}

Disturbances in natural circulation of heavy metals, caused by man's activites, are one of the causes of aquatic pollution which leads to an intensified bioaccumula- 
tion of the metals in fish and other aquatic animals. The bioaccumulation process in ichthyofauna is affected by a number of factors, the major role being played by the concentrations and chemical form of the metals in the environment. Protasowicki (1987) reviewed publications dealing with the factors and their interrelationships.

It is very difficult to state with certainty whether metal contents observed in an organism are natural or related to the habitat contamination. For this reason, studies in areas relatively protected from exposure to pollution bring important information, although certain pollutants exhibit a global range.

The objective of the present study was to determine, in a preliminary way, the degree of bioaccumulation of heavy metals in representatives of flora and fauna of the south-western part of Spitsbergen.

\section{MATERIALS AND METHODS}

Individuals of Arctic charr [Salvelinus alpinus (L.)] were caught in River Revelva (6 in 1985, 3 in 1986), Lake Revvatnet (1 each in 1985 and 1986), and Lake Svartvatnet (38 caught on 20 July 1986). Whenever possible, the following fish organs and tissues were analyzed for heavy metals: muscles, gills, liver, kidney, gonads, spleen, fins, bones, and eyes. It was also possible to analyze stomach content of a male caught in River Revelva in 1985. In 1985, samples of wreck bladder, barnacles, and gammarid amphipods were collected on Rotjespynten Cape, while euphausiid crustaceans were sampled in Hornsund Fjord.

The mercury content was determined using cold vapour atomic absorption spectrometry (CV AAS) in samples combusted as in Adrian (1971). The remaining heavy metals $(\mathrm{Cd}, \mathrm{Pb}, \mathrm{Cu}$ and $\mathrm{Zn})$ were determined with flame atomic absorption spectrometry (FAAS) in dry-combusted samples after dissolving the combustion residue in $15 \%$ $\mathrm{HNO}_{3}$ (Protasowicki 1985). Heavy metal contents were calculated from calibration curves plotted by means of the additives method. Blanks were analyzed concurrently and the results included in final calculations.

\section{RESULTS}

To facilitate comparisons, all the results are expresşed as $\mu \mathrm{g} \cdot \mathrm{g}^{-1}$ dry weight.

The data summarized in Tables 1 and 2 show that the levels of different heavy metals in aquatic organisms from the Hornsund area depended on an organism's position in the food chain. In terms of contents of various metals, the organisms studied can be ordered in the following way: 
Heavy metal content in certain plants and animals in the Hornsund region

\begin{tabular}{|c|c|c|c|c|c|c|}
\hline \multirow{2}{*}{$\begin{array}{l}\text { Sampling site } \\
\text { Species }\end{array}$} & \multicolumn{5}{|c|}{$\begin{array}{l}\text { Heavy metal content * } \\
\qquad \mu \mathrm{g} \cdot \mathrm{g}^{-1} \text { d.w. }\end{array}$} & \multirow{2}{*}{$\begin{array}{c}\text { Dry weight } \\
\text { content } \\
(\%)\end{array}$} \\
\hline & $\mathrm{Hg}$ & Cd & $\mathrm{Pb}$ & $\mathrm{Cu}$ & $\mathrm{Zn}$ & \\
\hline \multicolumn{7}{|l|}{ Retjespynten Cape } \\
\hline Wreck bladder & 0.025 & 0.917 & 5.06 & 5.59 & 30.02 & 24.32 \\
\hline Barnacles & nf & 0.880 & 5.82 & 2.93 & 19.54 & 40.90 \\
\hline Gammarids & 0.019 & 1.571 & 12.26 & 26.12 & 64.82 & 15.66 \\
\hline \multicolumn{7}{|l|}{ Hornsund Fjord } \\
\hline Euphausiids & 0.047 & 1.442 & 7.92 & 17.24 & 61.02 & 23.37 \\
\hline tatas & & & & & & \\
\hline
\end{tabular}

* mean value from three replicates

nf $=$ not found 
Table 2

Heavy metal contents in Arctic charr in River Revelva and Lake Revvatnet

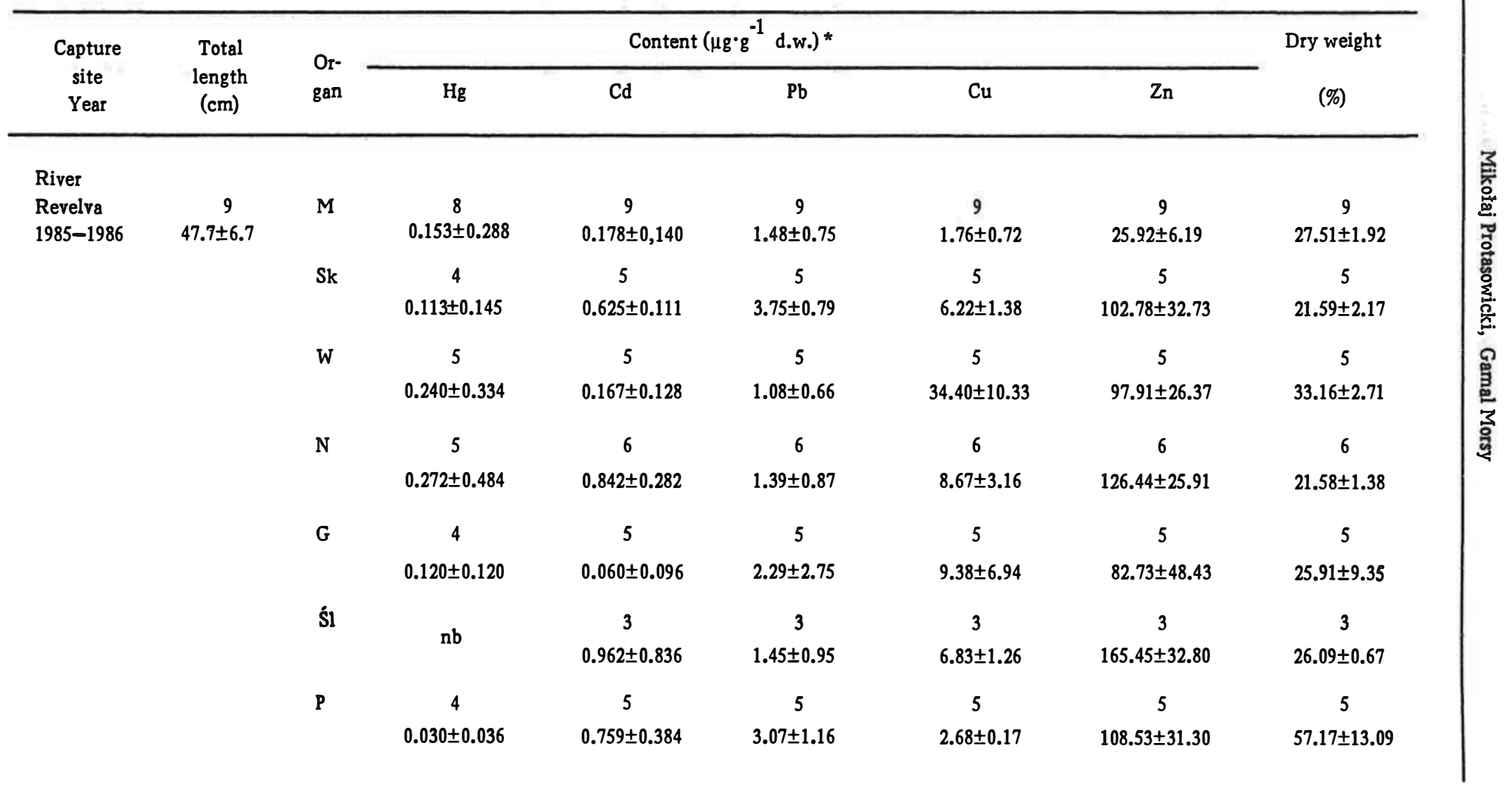


cd. table 2

0

4
$0.041 \pm 0.038$

5
$0.320 \pm 0.168$

Lake

Revvatnet

1985-1986



M

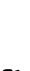

1

0.046

Sk

1
0.135

N

1

0.163

G

nb

$\mathbf{P}$

0

2
$0.157-0.234$
1
0.419
1
5.776

1

5.693

2

$0.787-9.293$

2

$0.207-0.698$

5
$1.42 \pm 0.68$

5

$3.74 \pm 1.51$

5

$281.43 \pm 47.83$

5

$33.69 \pm 2.64$

$0.025-1.120$

2
$0.99-1.93$
1
2.51
1
0.99
1
1.78
2
$3.73-5.95$
2
$0.47-1.42$

2
$0.85-2.71$
1
3.63
1
4.14
1
38.80

2
$25.68-67.40$
1
126.25
1
185.74
1
595.41

2

$21.75-23.84$

1

10.30

1

19.03

1

22.45

$2 \quad 2 \quad 2$

$2.45-3.23$

$128.91-141.43$

41.49-45.24

2

2

2

$1.39-3.45$

$261.43-514.69$

$27.50-31.67$

* upper line: number of fish examined: lower line: mean \pm standard

deviation or minimum and maximum values

$\mathrm{nb}=$ not studied

Abbreviations: $M$, muscles; Sk, gills; W, liver; N, kidney; G, gonads;

Śl, spleen; P, fins; $O$, eyes. 
Hg: barnacle < gammarid < wreck bladder $<$ euphausiid $<$ Arctic charr Cd: Arctic charr $<$ barnacle $<$ wreck bladder $<$ euphausiid $<$ gammarid $\mathrm{Pb}$ : Arctic charr $<$ wreck bladder $<$ barnacle $<$ euphausiid $<$ gammarid Cu: Arctic charr $<$ barnacle $<$ wreck bladder $<$ euphausiid $<$ gammarid $\mathrm{Zn}$ : barnacle $<$ Arctic charr $<$ wreck bladder $<$ euphausiid $<$ gammarid It should be pointed out that, when arraying the metal contents, the values used for fish are those found in muscles which form the bulk of fish body.

Table 2 summarizes data obtained from the few fish individuals caught in Lake Revvatnet and in the mouth of River Revelva, discharging from that lake. As seen from the table, it would be premature to conclude on differences between the two capture sites. On the other hand, the differences are evident when trace element contents are compared between the fishes from the two areas (Table 2) and from Lake Svartvatnet (Fig. 1). All the organs of the fish in the latter area showed a higher level of mercury, while some showed also a higher level of cadmium. The pattern of differences for other metals was much less clear.

Examination of one of the Arctic charr females revealed the presence of a 2-yr-old "old" roe not released during spawning and the "new" roe produced thereafter. The analyses (Table 3) showed the "old" roe to be greatly hydrated and to have higher contents of mercury, cadmium, and lead, while copper and zinc contents were lower than those in the "new" roe.

It was possible to sample stomach content of an Arctic charr individual from River Revelva and to determine heavy metal contents in the true food of the species. Mean contents of $\mathrm{Cd}, \mathrm{Pb}, \mathrm{Cu}$, and $\mathrm{Zn}$, calculated from three replicate assays for each metal, were: $8.585 ; 7.18 ; 14.11$; and $216.10 \mu \mathrm{g} \mathrm{g}^{-1}$ dry weight, respectively, the dry weight content being $16.02 \%$.

Lake Svartvatnet yielded the most representative material consisting of fish (21 females and 17 males) caught on one day. Such an ample material allowed between-sexes comparisons. Females and males had similar mean lengths $(50.0 \pm 4.6 \mathrm{~cm}$ and $52.5 \pm 5.1 \mathrm{~cm}$, respectively); no significant difference could be found (Student's $t$ test) between the two means.

As seen in Fig. 1 a-f, statistically significant between-sexes differences were found in 12 cases out of 54, 3 differences concerning dry weight (Student's $t$ and Aspin-Welsch tests). However, tests for homogeneity of variances ( $F$ test) carried out prior to comparisons of means showed significant qualitative differences to exist between heavy metal contents in females and males. The finding should be interpreted as meaning that, in spite of impossibility of demonstrating the differences in mean element levels, the ranges of the microelements studied differed between sexes (Fig. 1). Considerable qualitative between-sexes differences were found in to involve mercury content in gonads; cadmium in bones and eyes; lead in muscles, liver and fins; copper in liver, spleen, fins and eyes; and zinc in muscles, kidneys, spleen, fins, and eyes. 
Table 3

Heavy metal contents in two types of roe found in a female

\begin{tabular}{|c|c|c|c|c|c|c|}
\hline \multirow{2}{*}{ Roe type } & \multicolumn{5}{|c|}{ Content $\left(\mu \mathrm{g} \cdot \mathrm{g}^{-1}\right.$ d.w.) * } & \multirow{2}{*}{$\begin{array}{c}\text { Dry weigh } \\
\text { content } \\
(\%)\end{array}$} \\
\hline & $\mathrm{Hg}$ & $\mathrm{Cd}$ & $\mathrm{Pb}$ & $\mathrm{Cu}$ & $\mathrm{Zn}$ & \\
\hline "Old" & 1.647 & 0.429 & 3.46 & 6.84 & 39.10 & 13.30 \\
\hline "New" & 0.051 & 0.102 & 2.32 & 8.06 & 65.72 & 33.26 \\
\hline
\end{tabular}

${ }^{*}$ mean value calculated from three replicates 


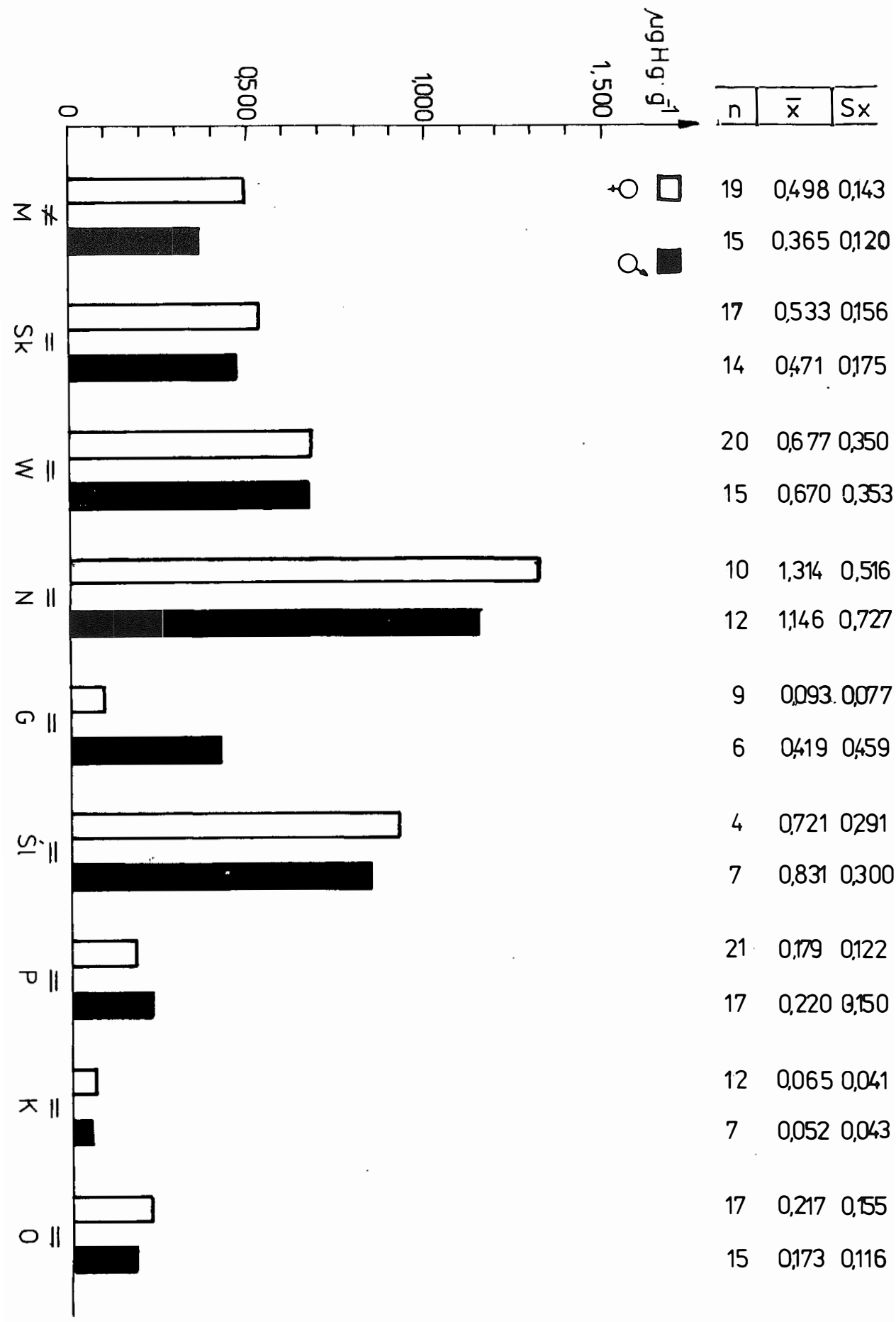




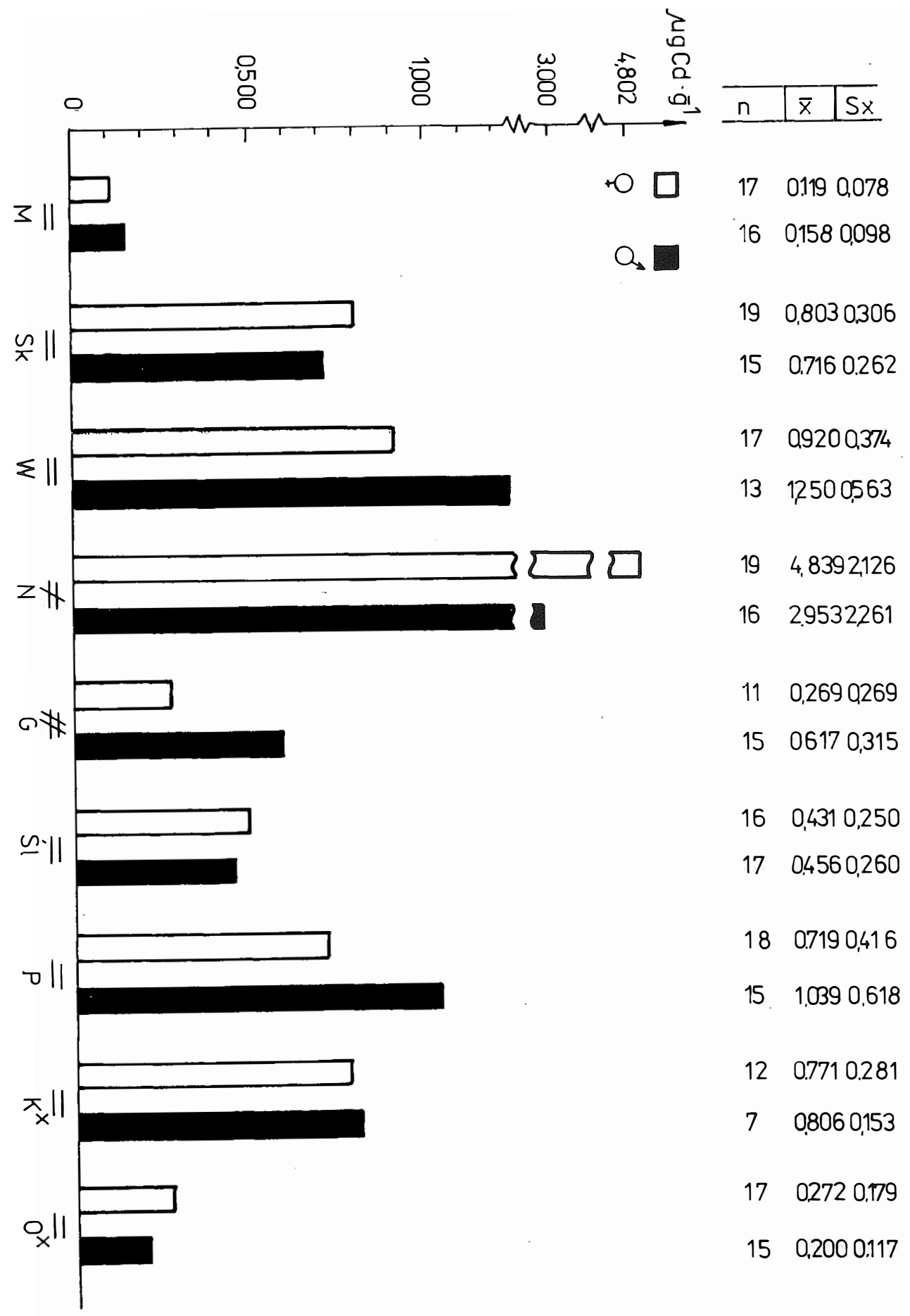









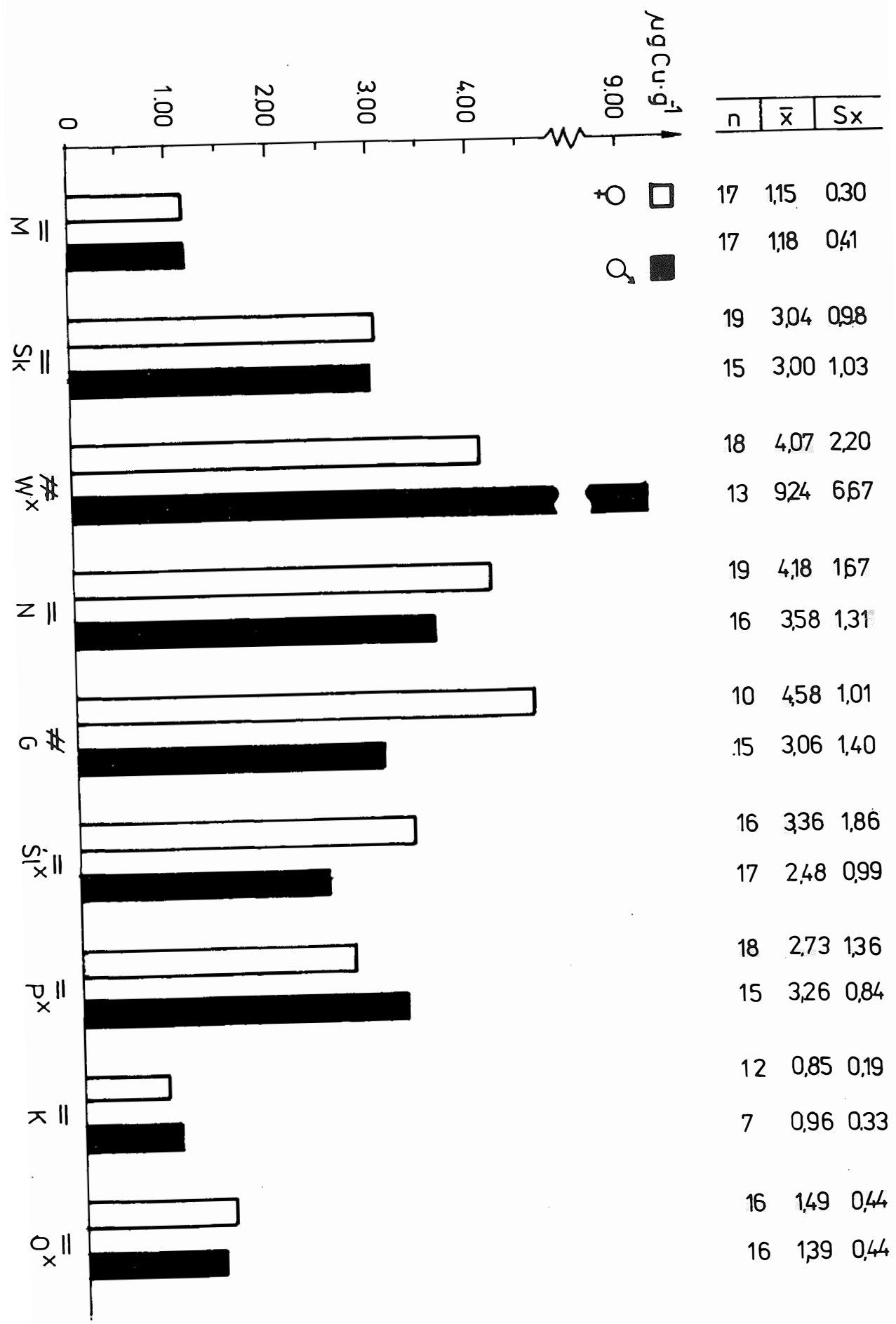




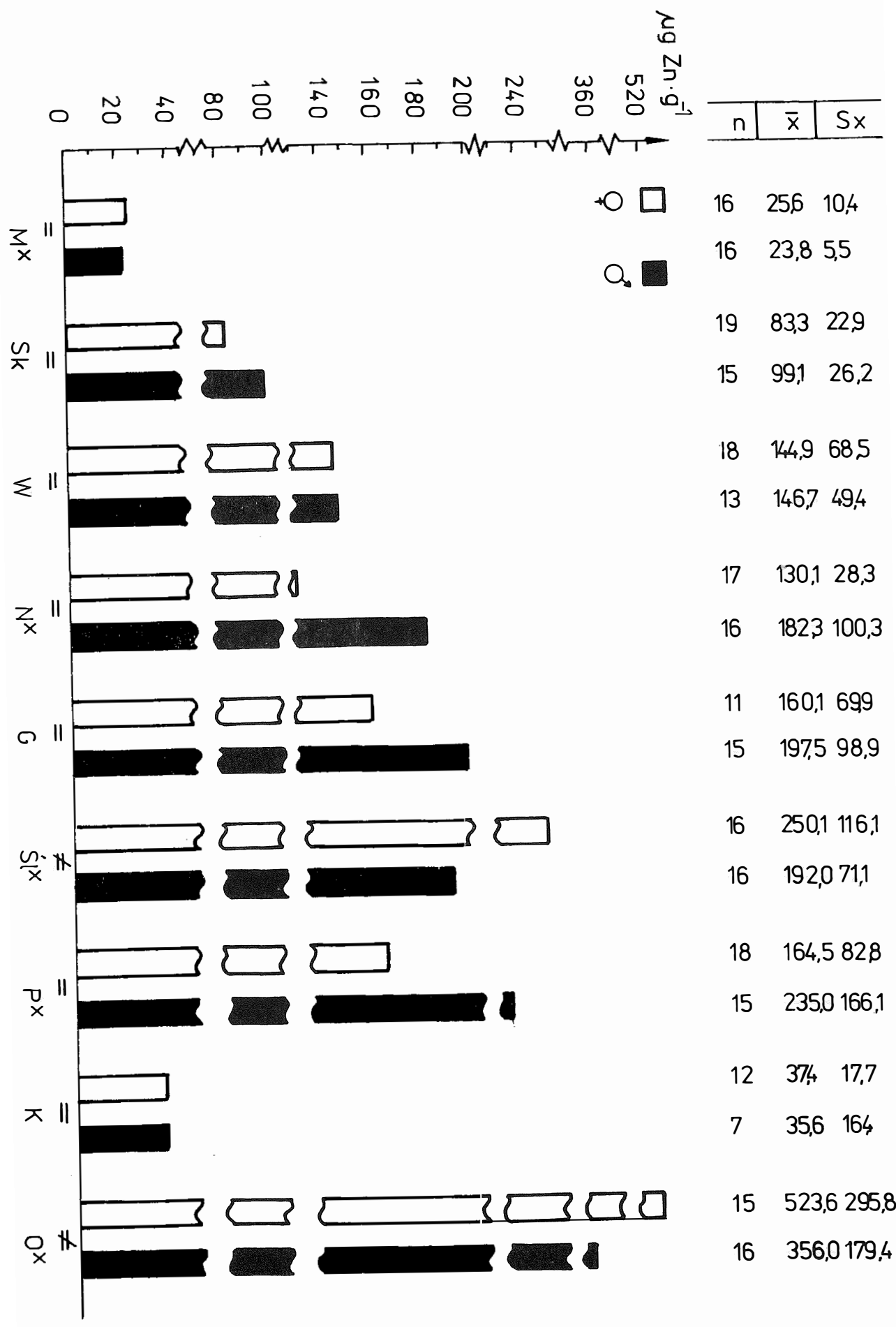




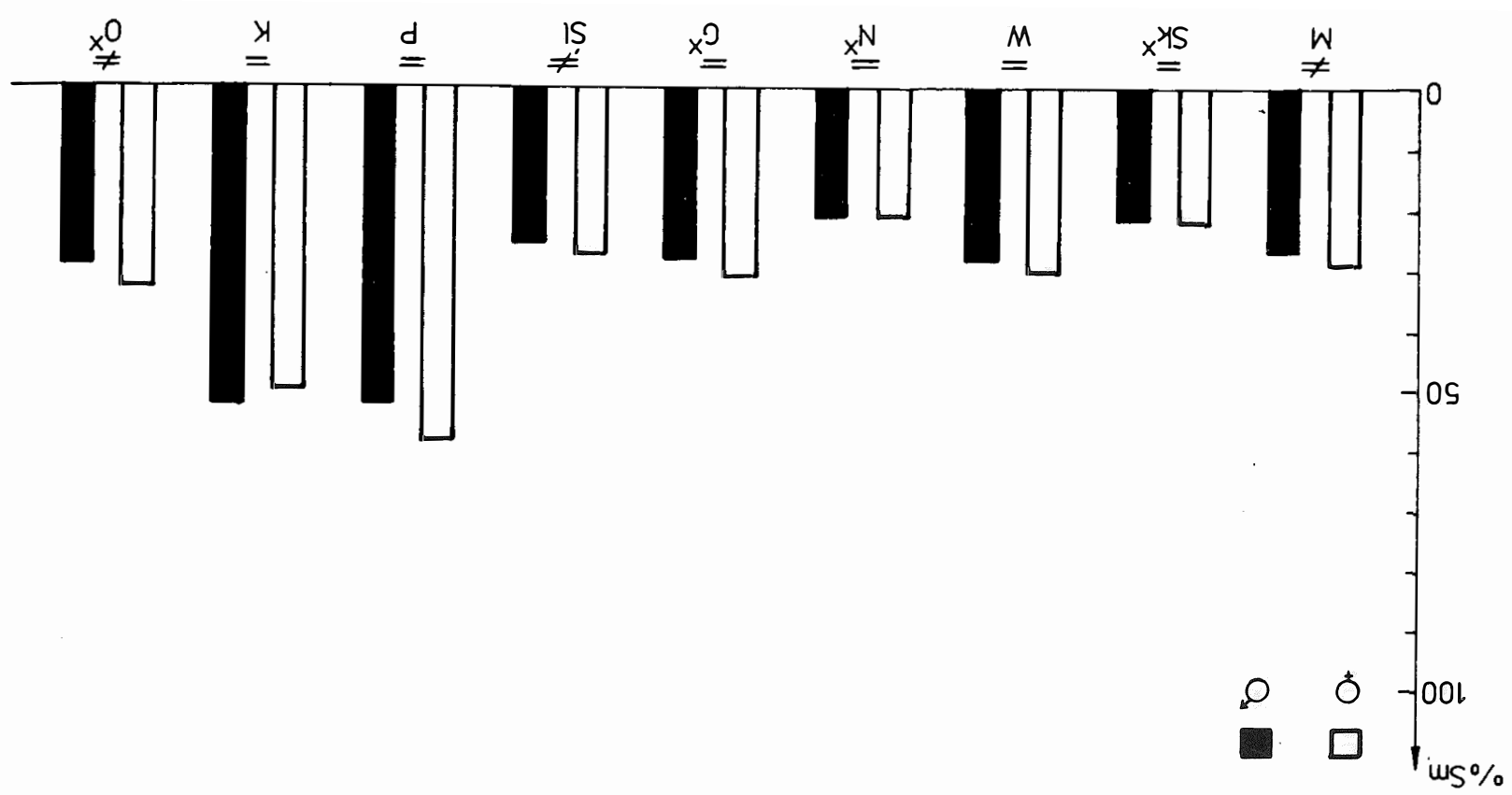

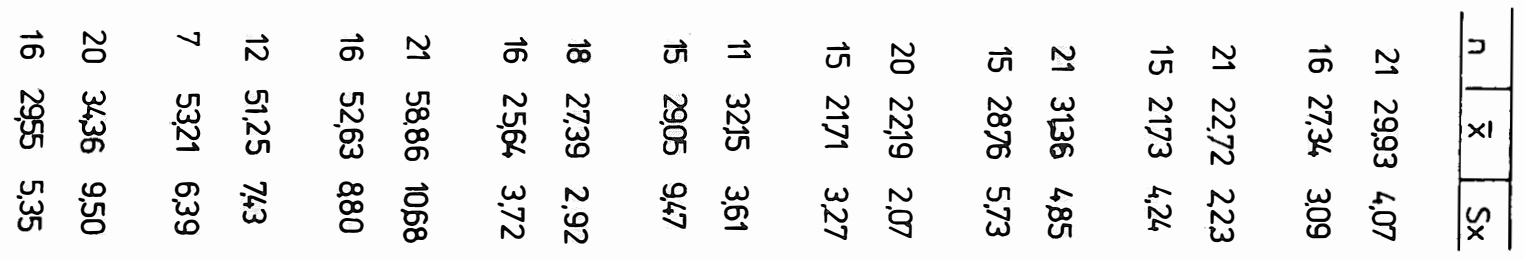

Fig. 1. Comparison between heavy metal and dry weight contents in selected organs of females ( $\%$ ) and males ( $\delta$ ) of the Arctic charr [Salvelinus alpinus (L.)] $x$, qualitative differences; $=$, no quantitative differences; $\neq$, significant quantitative differences; $\neq$, highly significant quantitative differences M, muscles; Sk, gills; W, liver; N, kidney; G, gonads; Śl, spleen; P, fins; K, bones; O, eyes 
Comparison of the heavy metal contents in organs and tisues of the Arctic charr displays an extensive variability in levels of the elements. Generally, the organs can be arranged in the following orders in terms of their heavy metal contents: mercury: bones $<$ eyes $<$ fins $<$ gonads $<$ muscles (males) $<$ muscles (females) $<$ $<$ gills $<$ liver $<$ spleen $<$ kidneys

cadmium: muscles $<$ eyes $<$ gonads (females) $<$ spleen $<$ gonads (males) $<$ gills $<$ $<$ bones $<$ fins $<$ liver $<$ kidneys (males) $<$ kidneys (females)

lead: $\quad$ eyes $<$ gonads $<$ muscles $<$ spleen $<$ liver $<$ kidneys $<$ gills $<$ fins (females) $<$ fins (males) $<$ bones

copper: $\quad$ bones $<$ muscles $<$ eyes $<$ gills $<$ gonads (males) $<$ spleen $<$ fins $<$ $<$ kidneys $<$ liver (females) $<$ gonads (females) $<$ liver (males)

zinc: $\quad$ muscles $<$ bones $<$ gills $<$ kidneys (females) $<$ liver $<$ kidneys (males) $<$ $<$ gonads $<$ spleen $($ males) $<$ fins $<$ spleen (females) $<$ eyes (males) $<$ $<$ eyes (females).

It should be remembered that the differences between organs, shown above, were not always significant. However, the extreme values differed by one or even by two orders of magnitude.

\section{DISCUSSION}

The results presented show that, compared to the Arctic charr, organisms of lower trophic levels had much lower contents of mercury and clearly higher concentrations of cadmium, lead, and copper, the zinc levels being similar or slightly higher than those in the fish. Thus biomagnification, i.e. icreasing contents of an elements up the trohic chain, does not involve all the heavy metals studied in this work.

Comparison of the data reported here with those supplied by salmonids of the Western Pomerania: the trout, Salmo trutta morpha trutta (Protasowicki, 1986), and the rainbow trout, Salmo gairdneri (Protasowicki et al., 1983) shows the heavy metal level in the Arctic charr to be only slihtly different than that in the salmonids mentioned. The Arctic charr muscles had cadmium levels lower than those in the trout, the contents being, however, comparable with those found in the rainbow trout. The zinc level, similar in muscles of the Arctic charr and rainbow trout, was in the first higher than that in the trout. On the other hand, ranges of lead and copper contents showed no significant differences. One should bear in mind that the papers referred to lack data on mercury contents.

The preliminary data on heavy metals in the Arctic charr inhabiting various water bodies in the Hornsund area show sitedependent differences. Capture site - and time-dependent variability in heavy metal contents in a fish species has been known 
from other studies, i.a. those of the first author (Protasowicki, 1986, 1987) and has been explained by differential contamination of various areas with heavy metals and seasonal differences in the contamination. However, in the case of migratory fishes, it would be very interesting to compare those living in the sea and river mouth, i.e. getting ready for ascent to spawn, and those staying in the lake, i.e. those that have not left the freshwater habitat yet or have reentered it.

The few data on differences between heavy metal contents in the "old" and "new" roe obtained from the same female allow no far-fetching conclusions to be drawn. The data seem to point out, however, to an attempt on the part of the organism to deposit toxic element $(\mathrm{Hg}, \mathrm{Cd}$, and $\mathrm{Pb}$ ) in a waste material (the old roe) and to resorb the indispensable microelements ( $\mathrm{Cu}$ and $\mathrm{Zn}$ ).

Information on heavy metal contents in gammarids and euphausiids is important as those animals are food items for the sea-dwelling Arctic charr (Grфnvik and Klementsen, 1987). One should, however, remember that the stomach contents studied showed much higher levels of cadmium and zinc, similar content of lead, and a lower content of copper. Thus one can conclude that, when studying the role the trophic chain plays in bioaccumulation processes, it is more purposeful to determine the metal level in the entire food rather than in its components.

The between-sexes differences in heavy metal contents have been reported earlier (Protasowicki, 1986, 1987). A study involving assays on muscles, liver and gonads of 6 fish species allowed to detect a certain pattern whereby male gonads accumulated more $\mathrm{Cd}$ and $\mathrm{Pb}$ and less $\mathrm{Cu}$ and $\mathrm{Zn}$ than female gonads. It was further concluded that females had physiological mechanisms of protection against intoxication developed better than males. It was, moreover, demonstrated that copper, indispensable in the embryonic development (Vorobiev, 1979) is accumulated in the ovaries and their products in amounts higher than in the testes and is taken up from the liver. Results obtained in the present study are in agreement with earlier data. Additionally, the presence of a barrier between blood and ovaries and their products is confirmed by the narrow range of mercury contents in the material. Among the intersexual differences, noteworthy is a clearly higher cadmium level in female kidneys (Fig. 1b). Is it indicative of a higher, compared to males, excretion of this toxic element? At the same time, a reverse trend is visible in the content of zinc, an indispensable metal (Fig. 1e).

Statistically significant differences between males and females were taken into account when analyzing heavy metal levels in various organs. Wide variations in heavy metal contents in different fish organs, reported also by other workers (Bierman, 1967; Windon et al., 1973; Rehwoldt et al., 1976; Wright, 1976; Wharfe and Broek, 1977) stem from different roles of the metals in the fish body and different functions of the organs. The data presented allow to conclude that the Arctic charr muscles, as opposed to other organs, accumulated little heavy metals, a conclusions 
important in view of the utilization of the muscles as human food. A similar pattern in heavy metal distribution in fish body was demonstrated by the first author's studies on other fish species (Protasowicki, 1987).

\section{CONCLUSIONS}

1. An increase in a microlement content up the trophic chain ("biomagnification") was observed in mercury only. The cadmium, lead, and copper levels decreased, while the zinc level showed no larger fluctuations.

2. Studies on heavy metal transfer in the food chain should involve organism and their entire food rather than food components.

3. In spite of certain differences, the heavy metal levels in the Arctic charr of the Hornsund region does not deviate significantly from those found in salmonids of the Western Pomerania. The between-sites differences found in the Hornsund region suggest, however, that continuation of the work could possibly contribute to explanation of changes which occur when a fish migrates from the marine to a freshwater habitat and vice versa.

4. The sex of a fish has a major effect on heavy metal level in some organs. Females have developed better mechanisms of protection against toxic elements.

5. Various fish organs differ in their ability of accumulation the heavy metal studied $(\mathrm{Hg}, \mathrm{Cd}, \mathrm{Pb}, \mathrm{Cu}$, and $\mathrm{Zn})$, muscles occupying the lower end of the ability spectrum, which is important due to their utility in human consumption.

\section{AKNOWLEDGEMENTS}

The authors wish to thank Ms. Marta Stankowska-Radziun, M.Sc. and Dr. Krzysztof Radziun for the collection and delivery of the study materials.

\section{REFERENCES}

Adrian W., 1971: A new digestion method for biological material utilizing pressure. At. Absorpt. Newsl., 10, 4: 96.

Bierman S.A., 1967: Fizjologiceskaja rol mikroelementov $\mathrm{v}$ organizmie presnovodnych ryb - w: Obmen veš̌estv i biochimia ryb. Izd. Nauka. Moskva, 275-279. (in Russian).

Grdavik S., A. Klementsen, 1987: Marine food and diet overlap of cooccuring arctic charr Salvelinus alpinus (L.) brown trout Salmo trutta L. and atlantic salmon S. salar L. off Senja, N. Norway. Polar. Biol., 7, 3: 137-177. 
Protasowicki Mo, 1985: Comparison of techniques of fish sample preparation for heavy metals analysis by flame AAS. Proc. 24th CSI, Garmisch-Partenkirchen 15-20.09.1985, 3, Th I 046, 548-549.

Protasowicki $\mathrm{M}_{0}, 1986$ : Sex effects on $\mathrm{Cd}, \mathrm{Pb}, \mathrm{Cu}$ and $\mathrm{Zn}$ contents in selected fish organs. Baltic Sea Environment Proc., 19, 433-441.

Protasowicki Mo, 1987: Wybrane metale ciężkie w rybach Bałtyku Południowego. (Selected heavy metals in the Southern Baltic fish). Rozprawy AR Szczecin, 110. (in Polish)

Protasowicki M., Chodyniecki, A. Ociepa, 1983: Metale ciężkie w rybach przemysłowych poławianych w latach 1976-1980. (Heavy metals in commercial fish species harvested in 1976-1980). Zesz. Nauk. AR Szczecin, 103, 181-198. (in Polish)

Rehwoldt R., D. Karimian-Teherani, H. Altman, 1976: Distribution of selected metals in tissue samplles of carp, Cyprinus carpio. Bull. Environ. Contam. Toxicol., 15, 3: 374-377.

Vorobiev V.Io, 1979: Mikroelementy i ich primienienije v rybowodstwie. Piszcze. prom.: 183 pp. (in Russian).

Wharfe J.R., W.L.F. Broek, 1977: Heavy metals in macroinvertebrates and fish from Lower Medway Estuary. Kent. Mar. Pollut. Bull., 8, 2: 31-34.

Windom H., R. Stickney, R. Smith, D. White, F. Tæylor, 1973: Arsenic, cadmium, copper, mercury and zinc in some species of North Atlantic finfish. J. Fish. Res. Board Canada, 30, 2: 275-279.

Wright D.A., 1976: Heavy metals in animals from the North East Coast - Mar. Pollut. Bull., 7, 2: 36-38.

Translated: Dr. T. Radziejewska

Mikołaj PROTASOWICKI, Gamal MORSY

WSTĘPNE BADANIA ZAWARTOŚCI METALI CIĘŻKICH W ORGANIZMACH WODNYCH
Z REJONU HORNSUNDU ZE SZCZEGÓLNYM UWZGLEDNIENIEM GOLCA

(SALVELINUS ALPINUS L.)

\section{STRESZCZENIE}

Zaburzenie równowagi obiegu metali ciężkich w przyrodzie wskutek gospodarczej działalności człowieka prowadzi do podwyższonej bioakumulacji tych pierwiastków w rybach i innych organizmach wodnych. W latach 1985-1986 w rejonie Hornsundu pobrano próby morszczynu, pąkli, kiełży, krewetek i golców. Organizmy poddano analizie na zawartošc $\mathrm{Hg}, \mathrm{Cd}, \mathrm{Pb}, \mathrm{Cu}$ i $\mathrm{Zn}$. Rtęc oznaczano metodą CVAAS, a kadm, ołów, miedź i cynk FAAS. Porównanie danych zestawionych w tabeli 1 i 2 oraz na rysunku 1 wykazało, że zawartošc rtęci w organizmach kolejnych, wyższych poziomów troficznych rośnie (zjawisko biomagnifikacji).

Równolegle w stosunku do kadmu, ołowiu i miedzi pozwoliło ono stwierdzić zjawisko odwrotne. Ilošc cynku w badanych organizmach reprezentujących poszczegölne poziomy troficzne nie różniła się istotnie. Równocześnie zwrócono uwagę na to, że badanie przemieszczania metali ciężkich wzdłuż łańcucha troficznego powinno raczej obejmować organizmy $i$ ich pełny pokarm reprezentowany przez trešć żołądków, a nie jego składowe.

Na podstawie różnic między zawartością pierwiastków s̉ladowych w golcach poszczegölnych akwenów w rejonie Hornsundu (Tabela 2 i Rys. 1) wydaje się uzasadnione kontynuowanie prac $w$ celu wyjaśnienia zmian ich poziomu w czasie przechodzenia ryb ze śsodowiska morskiego do śródlądowego i odwrotnie.

Wykazano również, że poszczegölne narządy golca cechuje różna zdolnošc kumulowania $\mathrm{Hg}, \mathrm{Cd}, \mathrm{Pb}, \mathrm{Cu}$ i $\mathrm{Zn}$, a o poz' mie tych metali w niektórych organach decyduje niekiedy płeć ryby (Rys. 1). Stwierdzono przy przy tym, że miẹsinie pod względem zawartości metali ciężkich, wśród badanych narządów, mieściły się w koñcowej części szeregu. 
Autorzy uważajđ̨, że samice wykazujøి lepiej rozwinięty mechanizm obrony przed pierwiastkami toksycznymi.

Authors' address:

Received: 1991.05.24

Prof. dr hab. Mikołaj Protasowicki, dr Gamal Morsy

Zakład Toksykologii

Akademia Rolnicza

ul. K. Krölewicza 4

71-550 Szczecin

Polska (Poland) 